S3 Fig

\title{
MED19 protein
}

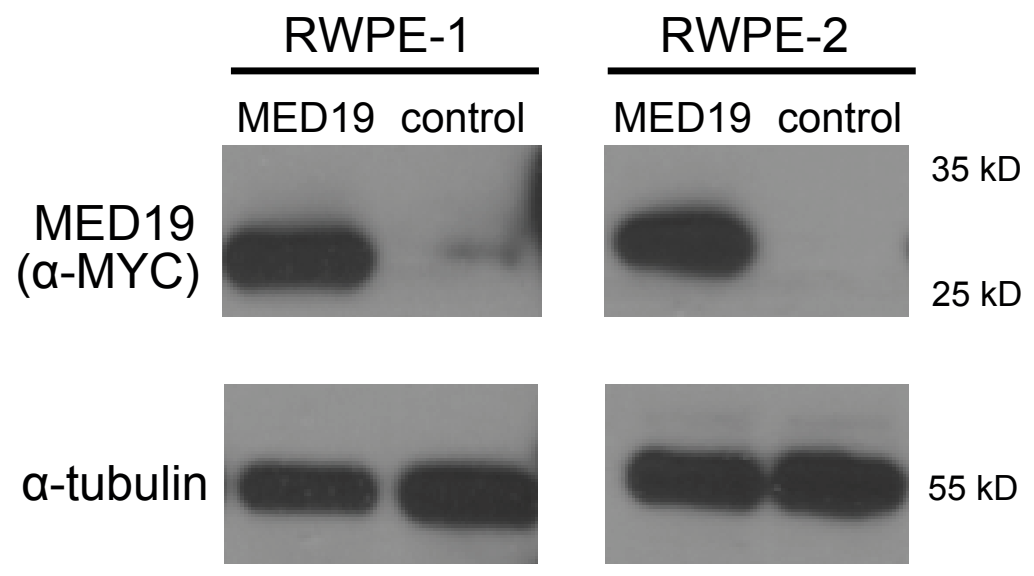

